INTERNATIONAL MULTIDISCIPLINARY SCIENTIFIC GEOCONFERENCES 17-26 June, 2014, Bulgaria

14th GeoConference on SCIENCE AND TECHNOLOGIES IN GEOLOGY, EXPLORATION AND MINING Conference Proceedings Volume III

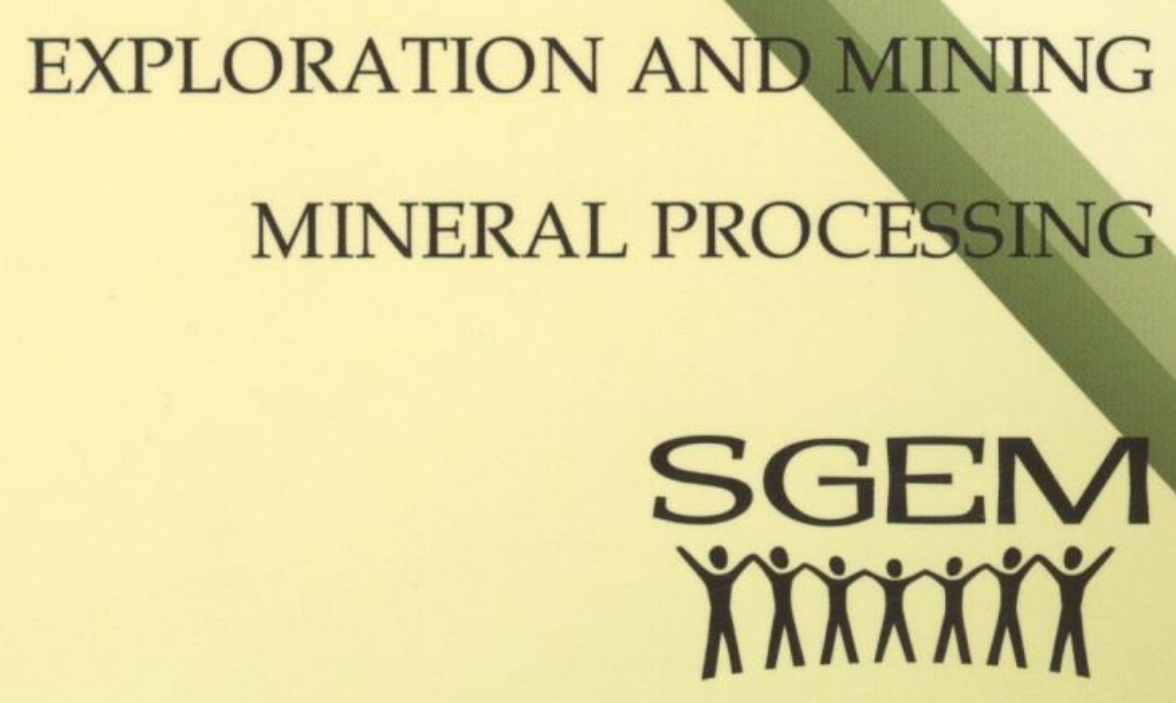




\section{DISCLAIMER}

This book contains abstracts and complete papers approved by the Conference Review Committee. Authors are responsible for the content and accuracy.

Opinions expressed may not necessarily reflect the position of the International Scientific Council of SGEM.

Information in the SGEM 2014 Conference Proceedings is subject to change without notice. No part of this book may be reproduced or transmitted in any form or by any means, electronic or mechanical, for any purpose, without the express written permission of the International Scientific Council of SGEM.

Copyright (C) SGEM2014

All Rights Reserved by the International Multidisciplinary Scientific GeoConference SGEM Published by STEF92 Technology Ltd., 1 “Andrey Lyapchev” Blvd., 1797 Sofia, Bulgaria Total print: 5000

ISBN 978-619-7105-09-4;

ISSN 1314-2704

DOI: $10.5593 /$ sgem2014B13

INTERNATIONAL MULTIDISCIPLINARY SCIENTIFIC GEOCONFERENCE SGEM Secretariat Bureau

Phone: $\quad+35929753982$

Fax: $\quad+35928741088$

E-mails: sgem@sgem.org | sgem@stef92.com

URL: www.sgem.org 


\section{CONFERENCE ORGANIZERS}

- BUlgARIAN ACADEMY OF SCIENCES

- ACADEMY OF SCIENCES OF THE CZECH REPUBLIC

- LATVIAN ACADEMY OF SCIENCES

- POLISH ACADEMY OF SCIENCES

- RUSSIAN ACADEMY OF SCIENCES

- SERBIAN ACADEMY OF SCIENCES AND ARTS

- SLOVAK ACADEMY OF SCIENCES

- NATIONAL ACADEMY OF SCIENCES OF UKRAINE

- INSTITUTE OF WATER PROBLEM AND HYDROPOWER OF NAS KR

- NATIONAL ACADEMY OF SCIENCES OF ARMENIA

- SCIENCE COUNCIL OF JAPAN

- THE WORLD ACADEMY OF SCIENCES (TWAS)

- EUROPEAN ACADEMY OF SCIENCES, ARTS AND LETTERS

- ACADEMY OF SCIENCES OF MOLDOVA

- MONTENEGRIN ACADEMY OF SCIENCES AND ARTS

- CROATIAN ACADEMY OF SCIENCES AND ARTS, CROATIA

- GEORGIAN NATIONAL ACADEMY OF SCIENCES

- ACADEMY OF FINE ARTS AND DESIGN IN BRATISLAVA

- TURKISH ACADEMY OF SCIENCES

- BULGARIAN INDUSTRIAL ASSOCIATION

- BULGARIAN MINISTRY OF ENVIRONMENT AND WATER

\section{HONORED ORGANIZER}

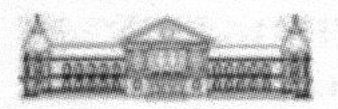

BULGARIAN ACADEMY OF SCIENCES

\section{EXCLUSIVE SUPPORTING PARTNER}

INTERNATIONAL SCIENTIFIC COMMITTEE

Science and Technologies in Geology, Exploration and Mining

- PROF. JEAN-PIERRE BURG, SWITZERLAND

- ACAD. DMITRY Y. PUSHCHAROVSKY, RUSSIA

- PROF. YEVGENY KONTAR, USA

- PROF HELMUT WEISSERT, SWITZERLAND

- PROF. KOEN BINNEMANS, BELGIUM

- PROF. PROSUN BHATTACHARYA FIL. DR., SWEDEN

- PROF. DR UNSAL YALCIN, GERMANY

- PROF. VLADICA CVETKOVIC, SERBIA

- PROF NIKOLAY I. LEONYUK, RUSSIA

- PROF. DR RADOSLAV NAKOV, BULGARIA 
- PROF. DR ZDENEK KALAB, CZECH REPUBLIC

- PROF. DSC JORDAN MARINSKI, BULGARIA

- PROF. VICTOR ARAD, ROMANIA

- PROF. YURY STEPIN, RUSSIA

- PROF. DR SNEZANA KOMATINA PETROVIC, SERBIA

- PROF. KUVVET ATAKAN, NORWAY

- PROF. K.N. MILOVIDOV, RUSSIA

- ASSOC. PROF. GERARDO BRANCUCCI, ITALY

- ASSOC. PROF. MARIAN MARSCHALKO, CZECH REPUBLIC

- ING. SLAVOMIR HREDZAK, PHD, SLOVAKIA

- DR. DIEGO PERUGINI, ITALY 
Vlad Pasculescu, National Institute for Research and Development in Mine Safety and Protection to Explosion - INSEMEX, Romania 537

71. SOCIAL EVALUATION OF MINING ACTIVITY EFFECTS, Ph.D. Michal Zasadzien, Silesian University of Technology, Poland.... 545

72. SPECIFICATION OF THE FIRM LIFE CYCLE IN CHOSEN INDUSTRIAL SECTOR, Assoc.prof. Lucia Domaracka, PhD., Mgr. Maria Muchova, PhD., Technical University of Kosice, Slovakia. .553

73. STRUCTURAL SAFETY OF MINING TAILINGS REFLECTED IN NATIONAL AND EUROPEAN REGULATIONS, PhD Student Eng. Paula Luminita Danciu, Coord. Prof. Dr.Eng. Dan Stematiu, Technical University of Civil Engineering Bucharest - Faculty of Hydrotechnics, Romania .559

74. STUDY OF 2K-52MU CUTTING AND LOADING MACHINE IN FACES WITH INDIVIDUAL SUPPORT IN LONEA MINE, Prof. Iosif Dumitrescu, Prof. Vilhelm Itu, Prof. Bogdan Cozma, University of Petrosani, Romania 567

75. STUDY ON THE PARTICULAR CONDITIONS OF THE MINING VENTILATION BY USING NUMERICAL METHODS, Eng.Marius Suvar,PhD.Eng.George A. Gaman,PhD.Eng.Constantin Lupu,PhD.Eng.Emilian Ghicioi,PhD.Eng.Doru Cioclea,Eng.Nicolae Vlasin,Prof. Victor Arad, National Institute for Research and Development in Mine Safety and Protection to Explosion - INSEMEX, Romania .575

76. SUBSIDENCE MODELING AT VALEA ARSULUI - VULCAN COLLIERY, Assoc. Prof. Dr. Adrian Florea; Prof. Dr. Maria Lazar; Lecturer Dr. Csabi Lorint, University of Petrosani, Romania. .583

77. SWOT ANALYSIS - POINT OF DEPARTURE FOR STRATEGIC MANAGERS, Assoc. Prof. Dr. Michal Vanek, Dr. Igor Cerny, Prof. Dr. Vlastimil Hudecek, Dr.Lucie Krcmarska, Dr.Jana Magnuskova, VSB-Technical University of Ostrava, Czech Republic

78. TAILING REFLOȦTING IN THE TREPCA MINES- PRISHTINA KOSOVO, Ramiz Krasniqi, Shaip Latifi, Ahmet Tmava, Sebahate Jonuzi, Ibush Jonuzi, Independent Commission for Mines and Minerals, Kosovo. .599

79. TECHNICAL DIAGNOSTICS IMPLEMENTATION INTO PRODUCTION PROCESS OPERATIONAL EXPERIENCES.,

Petr Vanek, Martin Prochazka, Iva Kudelova, Doc. Frantisek Helebrant, PhD. Ivan Bily, Severoceske doly a.s., Czech Republic

80. TECHNO-ECONOMIC PARAMETERS RELATED TO THE VRSHNIK CUAU ORE BODY, BUCHIM COPPER MINE, EASTERN MACEDONIA,

Full Prof. Dr. Todor Serafimovski, Kiril Filev, Doc. Dr. Goran Tasev, Assoc. Prof. Dr. Violeta Stefanova, University Goce Delcev, FYR of Macedonia. .615 


\title{
INFLUENCE OF THE BUCHIM COPPER LEACHING FACTORY ON THE ENVIRON AROUND THE ACTIVE BUCHIM COPPER MINE
}

\author{
Full Prof. Dr. Todor Serafimovski ${ }^{1}$ \\ Nikolajčo Nikolov² \\ Gerasim Konzulov ${ }^{2}$ \\ Doc. Dr. Goran Tasev ${ }^{1}$ \\ Sare Sarafiloski ${ }^{2}$ \\ ${ }^{1}$ Faculty of Natural and Technical Sciences, University “Goce Delčev"-Štip, R. Macedonia \\ ${ }^{2}$ DPTU Bučim DOOEL-Radoviš, R. Macedonia
}

\begin{abstract}
Within this paper we are going to present a review of results for some particular contaminants such are: $\mathrm{Co}, \mathrm{Cu}, \mathrm{Cd}, \mathrm{Al}, \mathrm{Fe}, \mathrm{U}$ etc., until the 2011 as well as review of results of monitoring (2012-2013) following the construction of the copper leaching facility. For the period covering period 1979-2011, in marked contrast, the water from the mine used to be acidic $(\mathrm{pH}<5)$ and had some dramatically high concentrations of particular elements: $75 \mathrm{mg} / \mathrm{L} \mathrm{Al}, 1.16 \mathrm{mg} / \mathrm{L} \mathrm{Co}$, $140 \mathrm{mg} / \mathrm{L} \mathrm{Cu}, 61 \mathrm{mg} / \mathrm{L} \mathrm{Mn}, 0.905 \mathrm{mg} / \mathrm{L} \mathrm{U}$ and etc. These very high values occurred within about $3 \mathrm{~km}$ of the mine but the influence of the mine extends downstream. For instance, the $\mathrm{Cu}$ concentrations used to be elevated ( $>0.5 \mathrm{mg} / \mathrm{L}) 24 \mathrm{~km}$ downstream, where the River Madenska joins the River Bregalnica. Positive effects in regards to environmental pollution following the construction of the leaching facility were confirmed by the results of the 2012 monitoring and especially by the results of the 2013 monitoring. According to the monitoring in 2013, copper values ranged from $<0.01$ to $1.6 \mathrm{mg} / \mathrm{L} \mathrm{Cu}$, silver in the range $0.001 \div 0.02 \mathrm{mg} / \mathrm{L}$ $\mathrm{Ag}$, ammonia $0.006 \div 0.90 \mathrm{mg} / \mathrm{L} \mathrm{NH}_{4}$ as well as $\mathrm{pH} 4.58 \div 7.86$, which itself speaks about the positive effects achieved with constructions of the leaching facility and engulfed drainage waters.
\end{abstract}

Keywords: leaching, Buchim copper mine, oxide ore, monitoring, contamination.

\section{INTRODUCTION}

Buchim Mine has been built 35 years ago on the well-known porphyry copper deposit Buchim. During these three and half decades of continuous production around the Buchim Mine were created surface waste dump where have been stored more than 130 Mt of waste and hydrotailing dam with more than $110 \mathrm{Mt}$ of tailing. These secondary landfills for years have been considered as basic sources of anthropogenic influences and contamination of air, soils and especially waters. Within the waste dump even today there are zones with $>0,1 \% \mathrm{Cu}$ as well as abundance of pyrite that continuously contributes as main acid mine drainage source to the draining streams of Jasenov Dol and outflow of Bucim's Lake, contaminating Madenska and Topolnicka River waters in prolonged period of time. Here we would like to stress out that the BuchimMine was is especially prone to the environment danger of acid mine drainage because all of the rocks there have lost their capability to buffer acids due to acid sulfide hydrothermal alteration and contrary to the fact that rocks of Buchim deposit contain less than $7 \%$, 
sulfides, since no carbonates are present to counteract the acid waters, the $\mathrm{pH}$ remained very low. This particular process of contamination lasted since 1979 until 2011 when below the waste dump was built copper leaching facility that for its process completely engulfed drainage waters in the area and Madenska River and river flows below were completely decontaminated.

Some of the preliminary publications that have studied the issues of mine pollution at the territory of the Republic of Macedonia, including area around the Buchim Mine, can be found in [1], [2], [3], [4], [5], [6], [7], [8], [9]. After that period studies around the Buchim Mine have been intensified and have been set monitoring points for particular hot spots around waste dump and tailing dam with associated water drainage, ambiental dust monitoring, monitoring of soil contamination etc. Considering that issue there have been completed some significant studies of soil contamination [10], [11], [12].

\section{METHODOLOGY}

Samples were collected during the continuous monitoring in 2011, 2012 an 2013 from the most environmentally threatening hot spots within the Buchim mine drainage system outlined below. Water was collected in polythene syringes, passed through a $0.45 \mu \mathrm{m}$ filter and transferred into polythene tubes. Water was acidified with $0.4 \mathrm{ml}$ of $50 \%$ nitric acid. Conductivity and $\mathrm{pH}$ were measured in the field for all water samples. Samples were stored in a cool and dark place until they were returned to the laboratory analysis. Solutions were analysed by ICPAES or ICPMS, depending on concentrations. A large number of analytes were determined but only those that are likely mining related and environmentally significant are presented and discussed here. The concentrations were compared to reference guidelines (Maximally Allowed Concentrations-MDK) to assess their significance.

\section{ACID MINE DRAINAGE SYSTEM}

There are several areas at the Buchim Mine system that are of particular environmental concern: the open pit, the heap leach pad, waste dump, tailing dam and the system of underground fractures that control groundwater movement. Short term environmental concerns include the presence of cyanide and metal rich solutions in the leach pad, while the long term environmental concern is acid mine drainage. Although acid drainage is commonly associated with the extraction and processing of sulfide-bearing metalliferous ore deposits, acidic drainage can occur wherever sulfide minerals are excavated and exposed to atmospheric oxygen [13]. BuchimMine is especially vulnerable to the environment danger of acid mine drainage because all of the rocks there have lost their capability to buffer acids due to acid sulfide hydrothermal alteration. In fact, the rocks of Buchim deposit contain less than 7\%, sulfides, but because no carbonates are present to counteract the acid waters that have passed through the ore body, the $\mathrm{pH}$ remains very low. The acid mine drainage has the most potential to affect water quality in the downstream agricultural and wetland areas of the Damjan Field and Kriva Lakavica Valley.

\section{WATER CONTAMINATION BEFORE THE CONSTRUCTION OF LEACHING FACILITY}

In the adjacent vicinity of the Buchim Mine have been located few important pollutants: Buchim open pit, Buchim waste dump and Buchim hydrotailing dam (Figure 1). 


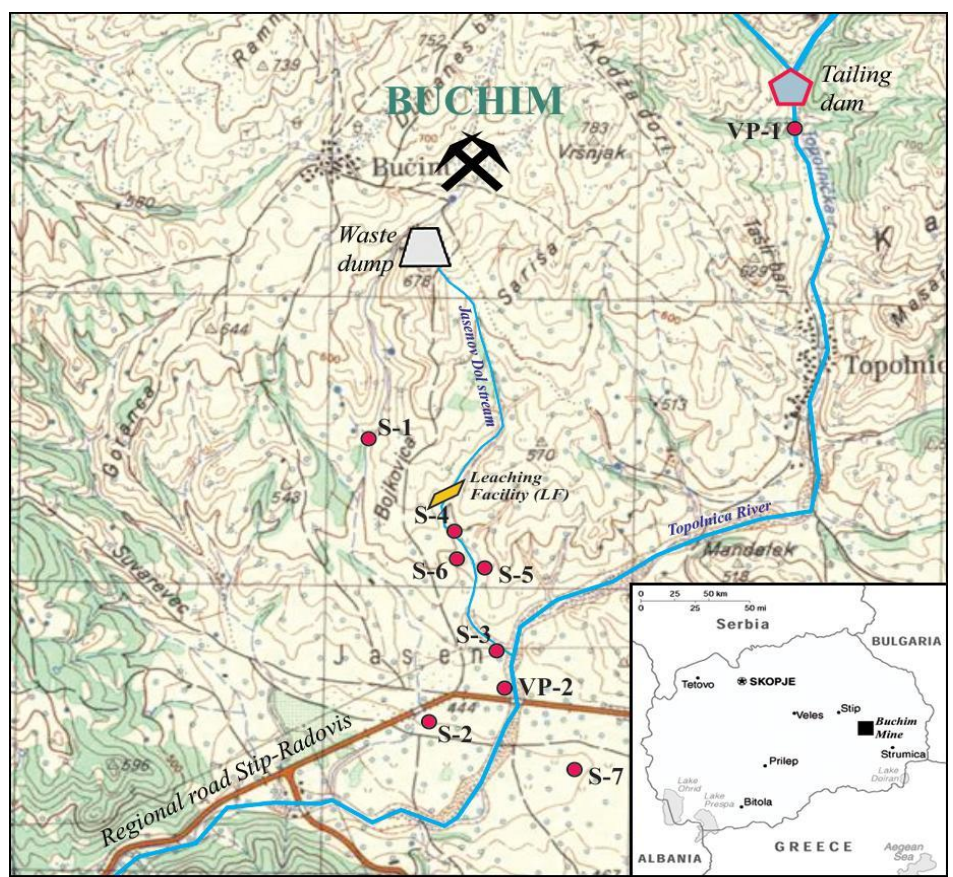

Figure 1. Topographic map of the Buchim Mine area with monitoring points

Draining waters from the mine waste are composed of meteoric waters flowing from upper parts above the mine waste pile (mine yard and Buchim village area) and passing through the mine waste, rain waters passing though the mine waste dump and flowing further downstream and ground waters infiltrating through the mine waste dump. Buchim Dol (Buchim Lake)-before the start of mine production it was built drainage system/collector, with channels around the location perimeter planned for the mine waste dump, draining into the Madenska River (Figure 2). Also, the hydrotailing dam is one pollutant, which drainages through the Topolnicka River. The negative influences of the Buchim pollutants clearly can be seen at the Figure 2a where the water in Madenska River is absolutely blue as a direct result of pollution.
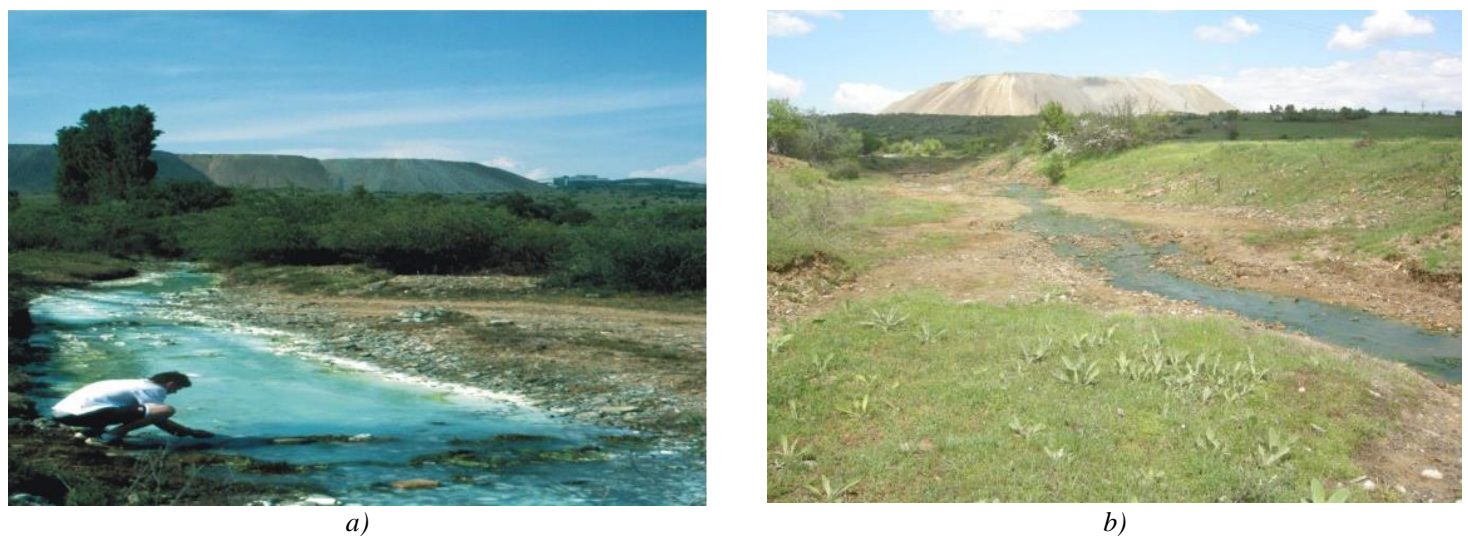

Figure 2. Madenska River before the construction of the leaching facility (a) and Madenska River after construction of the leaching facility (b)

In Table 1 are shown measured copper concentration values by months through 2010 in samples from 5 sampling points. The highest concentrations of copper were determined for the first seven months of 2010 (and earlier monitoring years) at monitoring points M2 
(Topolnica River, under the bridge on the road Radovis-Stip, range $0.3 \div 68.6 \mathrm{mg} / \mathrm{L} \mathrm{Cu}$ ), M3 (Buchim Dol, outflow from Buchim Lake, range 12.6 $\div 68 \mathrm{mg} / \mathrm{L} \mathrm{Cu}$ ), M4 (Jasenov Dol, outflow from the mine waste dump, range $113.1 \div 485 \mathrm{mg} / \mathrm{L} \mathrm{Cu}$ ).

Table 1. Copper concentrations in water samples from 5 monitoring points, around Buchim mine (in $\mathrm{mg} / \mathrm{L}$ )

\begin{tabular}{ccccccc}
\hline \multirow{2}{*}{ Month } & \multicolumn{6}{c}{ Copper concentration $\left(\mathbf{C u}^{2+}\right)$ at monitoring point (mg/l) } \\
\cline { 2 - 7 } & M1 & M2 & M3 & M4 & M5 & MDK \\
\hline 1 & 0,01 & 45,6 & 61,7 & 364,5 & 0,01 & 0,05 \\
\hline 2 & 0,01 & 0,96 & 19,4 & 147 & 0,01 & 0,05 \\
\hline 3 & $<0,01$ & 20,2 & 22,7 & 351,6 & $<0,01$ & 0,05 \\
\hline 4 & $<0,01$ & 3,46 & 12,6 & 113,1 & $<0,01$ & 0,05 \\
\hline 5 & $<0,01$ & 68,6 & 20,96 & 163 & $<0,01$ & 0,05 \\
\hline 6 & $<0,01$ & 30,5 & 41,5 & 194,6 & $<0,01$ & 0,05 \\
\hline 7 & $<0,01$ & 0,3 & 68 & 485 & $<0,01$ & 0,05 \\
\hline 8 & $<0,01$ & 0,07 & 0,104 & 0,02 & $<0,01$ & 0,05 \\
\hline 9 & $<0,01$ & 0,16 & 0,12 & 0,09 & $<0,01$ & 0,05 \\
\hline 10 & $<0,01$ & 0,41 & 0,24 & 0,23 & $<0,01$ & 0,05 \\
\hline 11 & $<0,01$ & 0,4 & 0,53 & 0,27 & $<0,01$ & 0,05 \\
\hline 12 & $<0,01$ & 0,28 & 0,53 & 0,33 & $<0,01$ & 0,05 \\
\hline
\end{tabular}

However, after the start of implementation of activities of the UNDP project, copper concentration values decreased almost instantly and below MDK values, which once again confirms the validity of activities applied. Almost the same thing occurred with $\mathrm{pH}$ values in formerly mentioned hot spots, M2, M3 and M4, where it was noticed significant increase of values from acid ones to almost neutral ones. This system collects part of draining waters from the mine waste dump and guide them to the Buchim Dol. Beside these waters, this gully constitutes of atmospheric waters redirected from open pit and ground waters under the mine waste. With the latest improvements, waters at the bottom of open pit have been pumped into the pools for industrial water because they are unpolluted and can be used again. The water samples analyses in 20082010 have been characterized by $30-45 \mathrm{mg} / \mathrm{L} \mathrm{Cu})$, low $\mathrm{pH}$ value $(3,6-5,5)$ and average flow of $15-201 / \mathrm{s}$. During the rainy periods it was noted that there is a process of dilution and were measured lower concentrations of the pollutants. Sudden increase of pollutants concentration has been measured after the confluence of acid drainage waste waters from the mine into the Topolnicka-Madenska River. In that manner copper concentration increases 25-40 times.

\section{RESULTS AND DISCUSSIONS FROM THE MONITORING IN 2012 AND 2013}

The latest monitoring of the ground and surface waters around the Buchim mine has been established after the construction of the copper leaching facility. The leaching facility has been located under the main waste dump of the Buchim mine and encompasses all the drainage surface waters from the waste dump and the Buchim mine. There is closed circular system for treated waters and surface waters are completely encompassed within the system. Studied monitoring sites of established piezometers have shown 
significantly lower values for copper and other parameters measured in 2012 and 2013 than those in period 2008-2010. These findings are given in the review below.

During 2012 we have monitored several water parameters. For the performed annual monitoring period measured parameters have shown wide range of values. For example: $\mathrm{pH} 3.60 \div 7.95$ (std. $6.0 \div 6.3$ ), height of water in piezometers $2.70 \div 7.70 \mathrm{~m}, \mathrm{HPK} \mathrm{MnO}_{4}$ $2.50 \div 97.90 \mathrm{mg} / \mathrm{l}$ (std. $5.01 \div 10.0 \mathrm{mg} / \mathrm{l}$ ), total residue at $105^{\circ} \mathrm{C}$ of $415 \div 8706 \mathrm{mg} / \mathrm{l}$, dissolved mater $410 \div 8266 \mathrm{mg} / 1$ (std. $1000 \mathrm{mg} / \mathrm{l}$ ), suspended mater $5 \div 1206 \mathrm{mg} / 1$ (std. $30 \div 60 \mathrm{mg} / \mathrm{l}$ ), copper $0.01 \div 0.68 \mathrm{mg} / 1$ (std. $0.05 \mathrm{mg} / \mathrm{l}$ ), silver $0.001 \div 0.02 \mathrm{mg} / 1$ (std. 0.02 $\mathrm{mg} / \mathrm{l}$ ), ammonia $0.06 \div 3.25 \mathrm{mg} / 1$ (std. $10 \mathrm{mg} / \mathrm{l}$ ), nitrates $3.50 \div 43 \mathrm{mg} / \mathrm{l}$ (std. $15 \mathrm{mg} / \mathrm{l}$ ), nitrites $0.07 \div 1.16 \mathrm{mg} / \mathrm{l}$ (std. $0.5 \mathrm{mg} / \mathrm{l})$ and total phosphates $0.01 \div 0.61 \mathrm{mg} / \mathrm{l}$ (std. $0.0071 \div 0.02$ ). From the review of the monitoring of ground and surface waters, around the Buchim mine, for the 2012, can be concluded that in most of the examined parameters we have the continuity of the measured values does not drastically differ from the standards for ground and surface waters. Surely as a main parameter in these research is copper whose concentrations are still continuing to hold our statistical review and is expressed through diagrammatic presentation. It is evident that copper concentrations even in these samples shows increased values in terms of standards, but however those concentrations are significantly lower in comparison to ones determined in waters around the Buchim mine before the construction and putting into operation of the copper leaching facility.

By analogy to copper, continuously increased values, mainly in piezometers, have been determined for nitrates, phosphates, dissolved solids and partly $\mathrm{HPK} \mathrm{KMNO}_{4}$. One of especially remarkable parameters that is continuously measured and which contribute to the increased solubility of particular elements in solutions is the $\mathrm{pH}$. Regarding this parameter we had certain decrease and deviation from neutral values. The lowest values of $\mathrm{pH}$ have been determined in piezometer S-3 during the monitoring in September, 2012, when the groundwater level was drastically low. During that period copper concentrations usually have shown increased values, too. Especially, here we would like to point out copper values for the above mentioned monitoring period in 2012 (Table 2).

Table 2. Mointoring of the copper concentrations in waters around the Buchim Mine (2012)

\begin{tabular}{lccccc}
\hline & $\begin{array}{c}\text { March, 2012 } \\
(\mathrm{mg} / \mathrm{l})\end{array}$ & $\begin{array}{c}\text { June, } \\
(\mathrm{mg} / \mathrm{l})\end{array}$ & $\begin{array}{c}\text { September, } \\
2012 \\
(\mathrm{mg} / \mathrm{l})\end{array}$ & $\begin{array}{c}\text { December, } \\
(\mathrm{mg} / \mathrm{l})\end{array}$ & $\begin{array}{c}\text { MDK } \\
(\mathrm{mg} / \mathrm{l})\end{array}$ \\
\hline VP-1 & 0,048 & 0,035 & 0,011 & 0,012 & 0,05 \\
\hline VP-2 & 0,032 & 0,021 & 0,012 & 0,017 & 0,05 \\
\hline S-1 & 0,021 & 0,020 & 0,010 & 0,011 & 0,05 \\
\hline S-2 & 0,048 & 0,500 & 0,510 & 1,640 & 0,05 \\
\hline S-3 & 0,004 & 0,140 & 0,320 & 0,410 & 0,05 \\
\hline S-4 & 0,017 & 0,050 & 0,011 & 0,010 & 0,05 \\
\hline S-5 & 0,353 & 0,060 & 0,330 & 0,460 & 0,05 \\
\hline S-6 & 0,221 & 0,023 & 0,013 & 0,030 & 0,05 \\
\hline S-7 & 0,012 & 0,680 & 0,640 & 0,340 & 0,05 \\
\hline
\end{tabular}

From the Table above it can be seen that in the majority of analyzed water samples have been determined higher concentrations than the maximally allowed concentrations (MDK) for copper in class III waters That there is a correlation between the measuring 
points and obtained copper concentrations in different periods of 2012, can be seen at the diagram below (Figure 3).

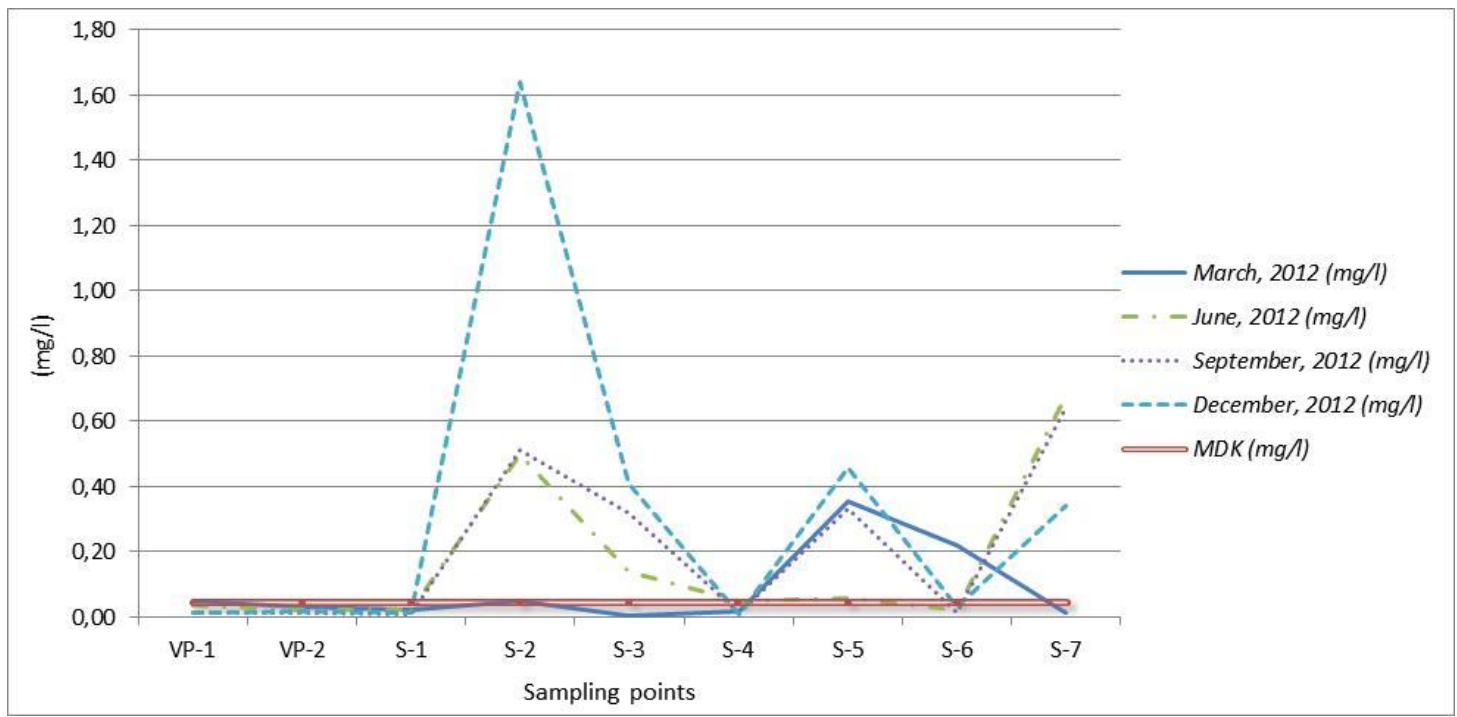

Figure 3. Diagram of copper distribution in the drainage mine waters around the Buchim copper mine in 2012

From the diagram above can be seen that values for all of the four monitoring of ground and surface waters in the adjacent vicinity o of the Buchim Mine remain synchronous. Joint feature of all samples that were analyzed is that the most of them had increased copper concentrations in comparison to the MDK values for the class III waters. At particular monitoring points such are S-2 and S-5, copper concentrations in all four monitoring periods have shown increased values. Also, it can be seen that at all four monitoring there is a continuity in copper values, which emphasizes the fact that the copper contaminations at certain points are directed by their persistent contamination sources. This is confirmed by the fact (Figure 3), that monitoring point S-2 and S-5 are positioned at the locations in which there is a administered inflow-outflow of surface or ground water. For S-2 that is the stream, which represents the outflow of contaminated water from Buchim Lake, while the monitoring point $S-5$ is located within the drainage system of Jasenov Dol, which drains water from the main waste dump.

Here we would like to stress out that the monitoring continued during the 2013 on the same points as in 2012 (Table 3).

Table 3. Mointoring of the copper concentrations in waters around the Buchim Mine (2013)

\begin{tabular}{lccccc}
\hline & $\begin{array}{c}\text { March, 2013 } \\
(\mathrm{mg} / \mathrm{l})\end{array}$ & $\begin{array}{c}\text { June, 2013 } \\
(\mathrm{mg} / \mathrm{l})\end{array}$ & $\begin{array}{c}\text { September, 2013 } \\
(\mathrm{mg} / \mathrm{l})\end{array}$ & $\begin{array}{c}\text { December, 2013 } \\
(\mathrm{mg} / \mathrm{l})\end{array}$ & MDK (mg/l) \\
\hline VE-1 & 0,15 & 0,01 & 0,01 & 0,01 & 0,05 \\
\hline VP-1 & 0,01 & 0,01 & 0,08 & 0,01 & 0,05 \\
\hline S-1 & 0,01 & 0,23 & 0,01 & 0,65 & 0,05 \\
\hline S-2 & 1,6 & 0,95 & 0,9 & 0,53 & 0,05 \\
\hline S-3 & 0,6 & 0,7 & 0,65 & 0,3 & 0,05 \\
\hline S-4 & 0,05 & 0,05 & 0,03 & 0,01 & 0,05 \\
\hline S-5 & 0,4 & 0,57 & 0,52 & 0,45 & 0,05 \\
\hline S-6 & 0,09 & 0,05 & 0,05 & 0,47 & 0,05 \\
\hline S-7 & 1,5 & 0,48 & 0,02 & 0,01 & 0,05 \\
\hline
\end{tabular}


From the Table above it can be seen that in the majority of analyzed water samples have been determined higher concentrations than the maximally allowed concentrations (MDK) for copper in class III waters That there is a correlation between the measuring points and obtained copper concentrations in different periods of 2013, can be seen at the diagram below (Figure 4).

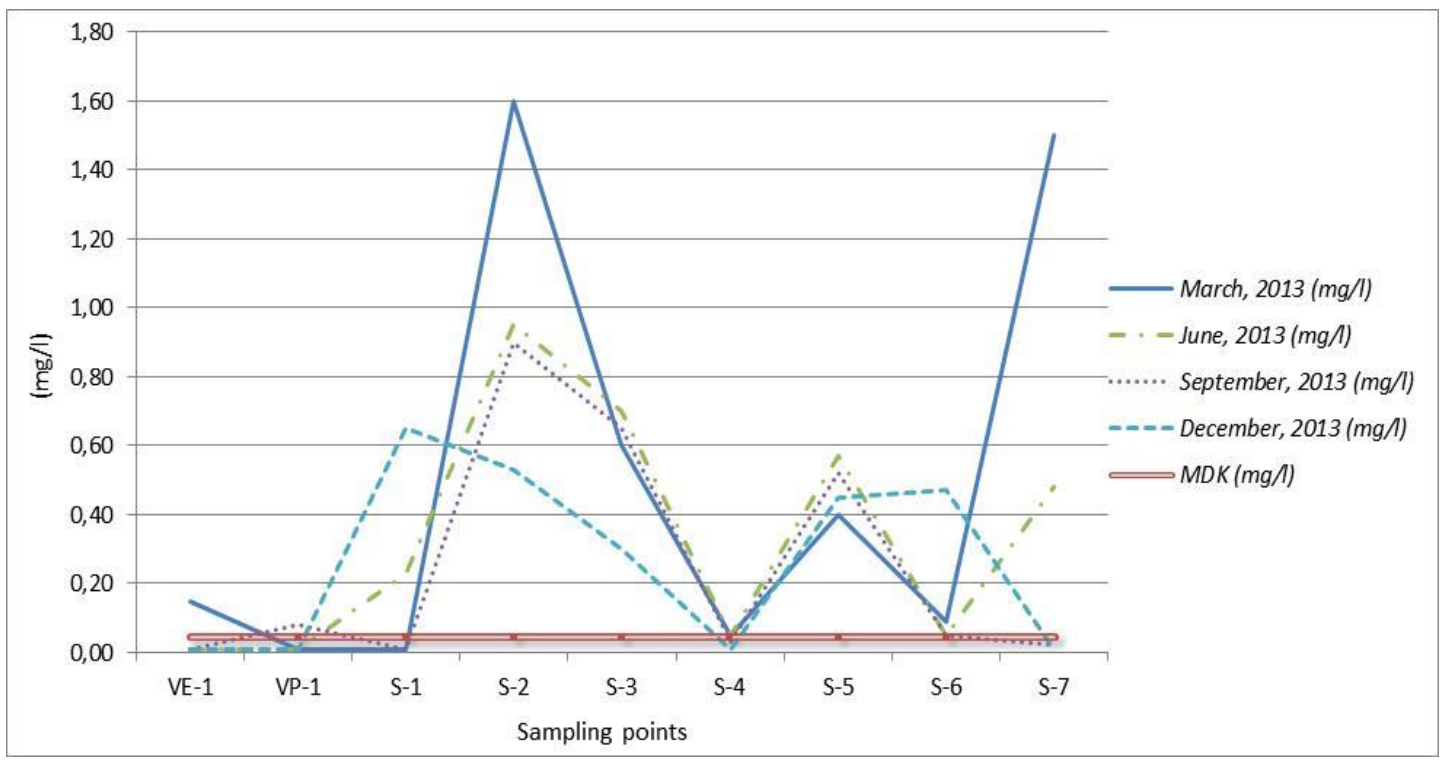

Figure 4. Diagram of copper distribution in the drainage mine waters around the Buchim copper mine in 2013

Also, there is a high compatibility of diagram patterns in Figure 3 and Figure 4, which speaks itself about the fact that diagram peaks are pointing to certain pollutants mentioned above, without time interference.

\section{CONCLUSION}

Few pollutants in the Buchim copper mine have been determined in the drainage system around the Buchim copper mine, which manifested pronounced acidic character of mine waters ( $\mathrm{pH} 3.6-5.5)$ and increased copper concentrations of up to $800 \mathrm{mg} / \mathrm{l} \mathrm{Cu}$. After the leaching facility was built the influence of pollutants to surface and ground waters significantly changed, which has been cinfirmed by latest monitoring performed in 2012 and 2013. From the review of the monitoring of ground and surface waters, around the Buchim mine for the 2012 and 2013, it can be concluded that for the most of studied parameters we have continuity of the measured values that does not drastically differ from the standards for ground and surface waters.

\section{REFERENCES}

[1] Serafimovski, T., Alderton, D.H.M., Mullen, B., and Fairall, K. Pollution Associated With Metal Mining in Macedonia. $32^{\text {nd }}$ International Geological Congress, Florence, Italy, Scientific Sessions: abstracts (part 1) - 362, 2004.

[2] Alderton, D.H.M., Serafimovski, T., Mullen, B., Fairall, K.,James, S. The chemistry of waters associated withmetal mining in Macedonia, Mine Water Environ.,V.24,pp.139-149, 2005. 
[3] Boev, B. and Lepitkova, S. Trace Elements in the Soils of Some Regions in the Republic of Macedonia. $2^{\text {nd }}$ Inter. Workshop on UNESCO-IGCP Project Anthropogenic effects on the human environment in Tertiary basins in the Mediterranean, Ljubljana, pp. 11-15, 2005.

[4] Bermanec, V., Žigovečki, Ž., Tomašić, N., Palinkaš, L.A., Kniewald, G.and Serafimovski, T. Stream sediment mineralogy as indicator of environmental impact of copper deposits exploitation in Buchim, Macedonia. $3^{\text {rd }}$ International Workshop on the UNESCO-IGCP Project: Anthropogenic effects on the human environment in Tertiary basins in the Mediterranean, Stip, $21^{\text {st }}$ October 2005, pp. 87-90, 2005.

[5] Serafimovski, T., Alderton, H. M. D., Dolenec, T., Tasev, G.,Dolenec, M. Metal pollution around the BučimMine; 3rd International Workshop on the UNESCO-IGCPProject: Anthropogenic effects on the human environmentin tertiary basins in the Mediterranean, Štip, 36-56., $2005 \mathrm{a}$

[6] Serafimovski, T., Alderton, H. M. D., Dolenec, T., Tasev, G., and Dolenec. M. Heavy metals in sediments and soils around the Bucim copper mine area.Geologica Macedonica, Stip. Volume 19, pp. 69-81., 2005b

[7] Serafimovski, T., Dolenec, T., Tasev, G., Rogan-Šmuc, N., Dolenec, M. and Vrhovnik, P. Pollution Related With Active Mines In The Eastern Macedonia. Proceedings of the $3^{\text {rd }}$ Workshop on the UNESCO-IGCP Project "Anthropogenic effects on the human environment in the Neogene basins in the SE Europe", Eds. T. Dolenec \& T. Serafimovski, Ljubljana, Slovenia, pp. 43-60, 2011a.

[8] Serafimovski, T., Mihajlov, M., Siderovski, K., Tasev, G. and Konzulov, G. Anthropogenic influence of the Buchim mine waste dump and hydrotailing to the surface and ground waters in the Lakavica basin, Macedonia. Proceedings of the $1^{\text {st }}$ Workshop on the UNESCO-IGCP Project "Anthropogenic effects on the human environment in the Neogene basins in the SE Europe", Eds. T. Serafimovski \& B. Boev, pp. 39-52., 2011b

[9] Serafimovski, T., Nikolov, N., Konzulov, G., Tasev, G. and Sarafiloski, S., 2013. Water monitoring around the Buchim copper mine drainage system. $13^{\text {th }}$ International Multidisciplinary Scientific GeoConference SGEM, Conference Proceedings, Volume 1 (Ecology, Economics, Education and Legislation), Albena, R. Bulgaria, pp. 1211-1218.

[10] Balabanova, B., Stafilov, T., Bačeva, K. and Šajn, R. Atmospheric pollution with copper around the copper mine and flotation, Bučim, Republic of Macedonia, using biomonitoring moss and lichen technique. GeologicaMacedonica, Vol. 23, pp. 35-41, 2009.

[11] Stafilov, T., Balabanova, B., Šajn, R.,Bačeva, K. and Boev, B. Geochemical Atlas of Radoviš and the environs and the distribution of heavy metals in the air.Facullty of Natural Sciences and Mathematics-Skopje; Faculty of Natural and Technical Sciences-Štip and Faculty of Agriculture-Štip.88 p.,2010.

[12] Mihajlov, M., Siderovski, K., Stafilov, T and Serafimovski T., 2011. Study of evaluation of environmental pollution. Professional fund of Buchim Company-Radovish, 171 p. (in Macedonian)

[13] Turekian, K.K.,. Treatise on Geochemistry, Ten Volume Set, Volume 1-10, 5155 p., 2003

[14] Schemel, LE., Kimball, BA., Bencala, KE. Colloid formation and metal transport through two mixing zones affected by acid mine drainage near Silverton, Colorado. Appl Geochem 15:1003-1018., 2000 